\title{
DOES CLIMATE CHANGE AFFECT PRICE OF VEGETABLES: EVIDENCE FROM TIGRAI, NORTHERN MOST ETHIOPIA
}

\author{
Berhe Gebregewergs ${ }^{1}$, Muиz Hadush ${ }^{2}$
}

\begin{abstract}
Although the agriculture economic sector in Ethiopia yet feeds enormous people, it's negatively impacted by climate change thereby contributed to the lower production and productivity. The research dealt therefore on the price effect of climate change on vegetable using time series data collected from 2009 to 20015 in Tigrai, Ethiopia. A univariate econometric analysis and finite distributed lag model were employed. In the descriptive part, due to climate change; tomato the vital vegetable consumed both in urban and rural population has recorded the highest inflation (211 percent) from 2009 to 2015 alone as compared to potato and onion. Whereas, potato and onion vegetables were rose up more than 152 and 154 percent consecutively on the same period. The average temperature increase of $1^{\circ} \mathrm{C}$ over the past seven years caused the price of tomato vegetable to increase more than threefold (310 percent) in 2015. Likewise, in the year 2010 as the temperature increased by $1^{\circ} \mathrm{C}$, the average price of tomato increased close to 155 percent, ceteris paribus. Even the price of tomato vegetables raised 118 percent in 2011 as compared to 2009. In 2013 and 2014, a $1^{\circ} \mathrm{C}$ rise in the average temperature cause close to 58 percent and 23 percent increase in the price of tomato, ceteris paribus. Moreover, the price increment of potato and onion vegetables is high. So as to get healthy vegetables often at fair prices both by the poor and rich in both the rural and urban population, applying outstanding climate adaptive strategies is recommendable.
\end{abstract}

Key words: Climate Change, Temperature, Time series, Tigrai, Vegetables Price.

JEL: $Q 01, Q 18, Q 51, Q 57$.

\section{Introduction}

Globally there are more than one point five billion people who are farming on less than two hectares of land (FAO et al., 2011). Around 80 percent of food consumed in some

1 Berhe Gebregewergs, MSc., Department of Economics, Mekelle University, Tigrai, Ethiopia. Phone: +251 9135514 91, E-mail: berhe.hareg@gmail.com

2 Muuz Hadush, Ph.D candidate, Lecturer at Mekelle University, Department of Economics P.o.box 451 Mekelle, Tigrai - Ethiopia, Phone: +251 9147022 81, E-mail: muuzba@gmail.com \& Ph.D student at Norwegian University of Life Science (NMBU), Norway, Phone: (+47) 9471 50 23, E-mail: muuz.hadush.gebremichael@nmbu.no

EP 2017 (64) 4 (1335-1354) 
Less Developing Countries (LDCs), especially, in Asia and Sub-Saharan Africa (SSA) that derived from smallholder agriculture. However, mostly the smallholders in LDCs immerse to price fluctuations repeatedly. In fact, the price ups and downs might be seasonal and expected sometimes. Large staple food consumption price soar impacts negatively on poor households more as compared to the rich ones since the have-nots spend just about three-quarters of their income on food consumption (Ben, Mehroosh, 2013).

Consumption of staple foods such as wheat, rice, maize, milk powder, oilseeds, vegetable prices were doubled and more in nominal terms in 2007 production year as compared to the lower food prices history in the last 25 to 30 years (Donald, 2008; Maros, Will, 2008; Demeke et al., 2009; WFP, 2011; WB, 2011; Kofi, 2012; Ben , Mehroosh, 2013).WFP and FAO (2011) stated that approximately one point zero two billion people of the World were undernourished since 2009 alone. Globally the fastest staple food consumption increments in the past years were caused social unrest or civil conflicts over 40 countries (WB, 2011). Though there are different debates on the causes of food price inflation by scholars, export bans by top wheat and rice producer countries, shifting food grains to biofuels, higher energy prices, a depreciating dollar, and increase food crops demand were the mostly agreed reasons among other factors (Donald, 2008). Moreover, global crop price and oilseed supplies deficiency due to poor harvests, change the eating habits of emerging economies because of income increase of the people were also the causes for consumption food price hikes (Tom, Joe, 2008). On the other hand, an amalgamation of both demand and supply side factors plus government policy decisions are the main causes for the staple foods of the world up (Kofi, 2012). The growing population and income in emerging economies and DCs is forecasted to cause a higher demand for food consumption in the coming decades. Unlike to the current seven billion population size of the globe, in the coming 2050 the globe's population has projected to reach nine billion people. Thus, this rapid population growth projection is predicted to bring among 70 percent to 100 percent rise in the demand of food consumption as compared to the 2007/08 world economic crisis (FAO et al., 2011).Even in the coming 2019, some scientific projections of intellects revealed that there will be an increment in the prices of staple consumer items, vegetables, and livestock outputs (Demeke et al., 2009; FAO, 2011). Therefore, this breaking news told the World that boosting the growth of food consumer items parallel to the present and coming demand of billion people for food is important; otherwise will outbreak food consumption hikes that lead at least to economic inequality and different social unrest in the globe continuously.

Ethiopia in the last years (2004/5 to 2007) for example, has had registered around 18 percent price rise in food and 16 percent for non-food (Jeni, Josef, 2007). The Ethiopian economy has registered extraordinary macroeconomic performance with the GDP of 11 percent for the last one decade (2004 to 2014) in the country's history (UNDP, 2014). This remarkable macroeconomic achievement is two-fold of what is in SSA and even makes Ethiopia one of the fastest emerging economies in the globe. There is no consensus on why Ethiopia experienced such dramatic food price rises yet. The Ethiopian inflation is primarily related to agriculture and food in the economy plus global 
food crisis. Unlike other food consumption items, vegetable crops due to their nature of pershability and seasonality forecasting their price soars are more sensitive (Kamau, 2014). Vegetables are important outputs in improving the livelihood of the people in giving a balanced diet thereby improving the health status of the people plus serves as a cash crop in generating income to households. Though Ethiopia has a comparative advantage in horticulture agriculture in many ways, fruit processing industries are scarce and are in importing vegetables and fruits (EIA, 2012). Moreover, the national inflation on foodstuffs has increased by 13.9 percent and non-food items increased by 9.7 percent in the year 2015 as compared to the inflation rate in July 2014 (Muluken, 2015).

The Intergovernmental Panel on Climate Change (IPCC) institution revealed that by 2030 close to 0.9 to $1.1^{\circ} \mathrm{C}$ mean annual temperature increase will be recorded in Ethiopia; however, the range would expect to rise from 2.7 to $3.4^{\circ} \mathrm{C}$ in 2080 in the country opposite to the $0.37^{\circ} \mathrm{C}$ (EEA, 2008). Countries in the Southern world are not the main originators of climate change; however, they may suffer the greatest share of damage in the form of declining agricultural outputs and greater frequency of extreme weather events (IMF, WB, 2011). Increased use of food crops for biofuel production would lead to more than 1.7 million undernourished children in Africa and Asia in 2050 unless the policy for is reconsidered. Parallel to the Sustainable Development Goals (SDGs) planned to achieve by 2030 which favors the vulnerable population, requires climate adaptive interventions in various countries, otherwise negligible (FAO, 2016). Climate variability has played a top role in causing the low level of agricultural outputs even in Tigrai and Ethiopia (CEEPA, WB, 2006; Gebreegziabher et al., 2014; Bezabih, Mokenen, 2014; Kassa Teka et al., 2012; Gebrekiros et al., 2016).

Climate change impacts negatively more on the _agriculture-based economies like Ethiopia. Whereas, there have been scanty researches done which investigate tomato, onion, and potato vegetable inflation using time series data in terms of the dynamic causal effect of prices and temperature in the Northern most part of Ethiopia. The general objective of the study was therefore to estimate the price effect of climate change on vegetable crops using time series data in Tigrai regional state of Ethiopia. More to the point examine the causal relationship between temperature and price of vegetables and the effect of own price lag on its current value.

\section{Related Literature Review}

Khan and Senhadji (2001) using a cross-country panel data have been produced the threshold level inflation for both DCs and LDCs concluded that a threshold level ranging from 11 to 12 percent for LDCs is fine for stabilized macroeconomic objectives and sustainable growth. However, above the specified inflation threshold, it can hurt the economic growth of LDCs. In the Ethiopian case, a research was done by Emerta (2010) using data 1971-2010 contended that a threshold of single digit inflation, especially 8 to 10 percent is convenient for having stabilized macro economy and economic growth (optimal inflation target policy). 
The Agriculture sector in Ethiopia which represents 40.2 percent of GDP grew by 5.4 percent, the industry also covers 14 percent of GDP and expanded by above 21.2 percent, and lastly the services economic sector that holds 46.2 percent of GDP rose by 11.9 percent in the last eleven successful years. Although many factors might be hindered not to keep the pace of this fastest economic growth in the coming years in Ethiopia, the economy is forecasted to keep growing due to the underway multi-sectoral transformation and the developmental state political commitment to achieve development (Admit et al., 2015). Vegetables are those plants which are consumed in relatively small quantities as a side-dish or a relish with the staple food (as cited in Seid, Yeshi, 2013). Either in the Ethiopian context or world widely, vegetables are useful at least for the following reasons. Thus, it can serve as a source of vitamins, minerals, roughage, neutralizing the acid substances, medicinal value, generating income, and food and social security. Agriculture economic sector is usually prone to climate change and worked under high risk and unpredictability condition. Furthermore, crop pricing also affects negatively the production because the prices of agricultural producers are price takers that have been determined by the interplay of demand and supply (H.Erdal et al., 2009).Vegetables, the especially potato is the high yielding crop and fourth food source in the world next to rice, wheat, and corn. Potato is nutritious and easy to digest grown in many environments and consumed in various parts of the globe (Aklilu et al., 2015; H.Erdal et al., 2009).

Even if Ethiopia has a comparative advantage in a number of horticultural commodities because of favorable climate, proximity to European and Middle Eastern markets and cheap labor: the production of horticultural crops is much less developed than the production of food grains in the country (EIA, 2012). The total area covered by fruits and vegetables is about 12,576 hectares in 2011. Of the total land area under cultivation in the country during the same year, the area under fruits and vegetables is less than one percent (which is 0.11 percent), implies that very small as compared to food crops. However, fruit processing industries are scarce. The 'Merti' processing factory is the only plant producing fruit juice for the local market. This investment gap witnessed that there is an investment motive to investors in Ethiopia (EIA, 2012).Today, large numbers of fruit juices are imported into the country because of high demand in fruit juice in homeland market. For example tomato; $951,920 \mathrm{Kg}$ with a total cost of 9,022,271 Birr in 2009; 1,509,352 Kg at a cost of 20, 671, 644 Birr; and 1,558, 240Kg with a total cost of 22,283,409 Birr tomato fruit juice has been imported to Ethiopia from abroad for juice consumption in the last 2009 to 2011. Due to lack of sufficient supply of fruit juice raw materials like tomato, orange, grape, apple, mixtures, and others at home, the country is in loosing huge hard currency. The demand for these fruit juice import items specified above is on average in an increasing direction. That demand supply mismatch also causes price up.

In the production year of Meher 2012/13, the productivity of tomato and onion vegetables per hectare of land by small farms revealed that under potential. Although there is an ample potential for the productivity of tomato and been proven that 159 to 463 quintal per hectare is the potential capacity of small farms, but in reality, small farms 
are in producing it at around 90 quintals per hectare. Similarly, the small farms are actually producing onion vegetable at around 102 quintals per hectare but below what is 350 to 400 quintals per hectare the maximum productivity potential (EIA, 2012). There are kinds of incentives devised by the Ethiopian government under regulation No.84/2003 including customs duty exemption, income tax exemption, and loss carries forward to attract investors in establishing fruit juice vegetables and other new enterprises. Furthermore, there are favorable and diverse climate, irrigable land, and geographic location or export market opportunities are found; however, shortage of quality high yielding varieties, disease and insect pests, shortage of skilled personnel, poor post-harvest handling, and weak production and market chain are the challenges to be solved soon so as to increase production and productivity of fruit juice vegetables (Endale, 2013). Like many other vegetables, onion is also a valuable vegetable highly consumed worldwide. China is the first largest onion producer country in the globe. Next, to China, India is the second largest onion vegetable producer with over 15million tones produce in 2010 to 2011 production year.

Honrao (2014) made a research on vegetables like onion and tomato in India found that price volatility estimated as the predictable variance is found to have increased after 2007 production year. The agricultural output was also adversely affected by deficient rainfall in the first two months of the monsoon period of June to September. By and large, the high rate of overall inflation and particularly onion inflation caused by weather change witnessed during 2011 and 2013 production years. An increase in the price of fruits and vegetables relative to less healthy foods could reduce consumers' incentives to purchase fruits and vegetables and result in less healthy diets (Fred, Hayden, 2008).

\section{Agricultural production and consequences of climate change}

A research done in 50 selected districts in diversified agro ecological zones of Ethiopia using the Ricardian model from 1000 sample farmers revealed as temperature increases, the agricultural yield reduces close to 998 US\$ in winter and 178 US4 summer seasons in net revenue per hectare(CEEPA,WB, 2006). "Of the world's production of fruit and vegetables, $42 \%$ is grown in China and India - more than one billion tonnes out of the total of 2.4 billion tonnes. China alone grows $38 \%$ of the vegetables and $19 \%$ of the fruit produced globally (tonnes measure). China produces $44 \%$ of the world's apple crop and $50 \%$ of the world's peaches and nectarines. India 's largest volume fruit crop is bananas (27 million tonnes). This is 28\% of global production in the year 2009(cited in Kamau, 2014)." Confidently, Ethiopian vegetable production ranging from gardening smallholder farming to commercial state and private farms that are largely produced include pepper, kale (Ethiopian cabbage), onion, tomato, pepper, chilies, carrot, garlic and cabbages as the major ones. However, the overall production yet is lower than what can possibly produce given its potential (Bezabih et al., 2014).Unlike other food consumption items, vegetable crops due to their nature of perish-ability and seasonality forecasting price soars is more sensitive (Kamau, 2014). Temperature has a large effect on the development of vegetables. 
"Climate change is a key concern to Ethiopia in our time and need to be tackled in a state of emergency. It has brought an escalating burden to already existing environmental concerns ofthe country including deforestation, serious soil erosion and loss of top soil and land degradation which in turn have adversely impacted agricultural productivity (Ayana et al., 2011)." "Over the coming decades, the global frequency and severity of drought is likely to increase as a result of climate change. Regional projections suggest that south-eastern Australia will be adversely affected by changes in rainfall patterns, as well as by rising temperatures, which increase the severity of drought. By 2070 there may be 40\% more months of drought in eastern Australia, and conditions will be worse in a high-emissions scenario (John, 2007). "By 2080-2100, African agricultural output is projected to reduce 15 to $30 \%$ due to the negative impact of climate change (IMF, WB, 2011). Rain fed agriculture is the usual custom, a good rainy season means good crop production, certify food security, and a healthy macro economy in Ethiopia. However, failure of rains and occurrence of natural disasters such as floods and droughts could lead to crop failure, food insecurity, famine, loss of property and life, mass migration and negative national economic growth (WB, 2005).

"In the short term, unfavorable weather conditions, coupled with high world prices for commodities such as grains, will increase input costs for a wide range of fresh and processed foods. The largest price rises are likely for fruit and vegetables and we can also expect significant price increases for products that rely on grains as an input (either directly or indirectly as a feedstock) such as bread, cereals and snack foods, dairy, eggs and meat in the future. For example, the Australian Egg Corporation has warned that the price of eggs will rise by 50 to 60 cents a dozen (or at least 10\%) (cited in John, 2007)." In the last 20 years many rural households perceived as the production of crop and livestock, and land productivity was declined due to the extremely unpredictable and erratic rainfall in Tigrai (Kassa Teka et al., 2012). Climate change in the past 32 years in Alamata, Tigrai negatively impacted sorghum crop production. However, the negative impact of temperature was larger than rainfall (Gebrekiros et al., 2016). For developing and initial growth of plants, a temperature of $22-24^{\circ} \mathrm{C}$ is the best for potato-vegetable (as cited in Seid, Yeshi, 2013). Contrary to what the world has had experienced in the $20^{\text {th }}$ century with an average surface temperature increase of around $0.6{ }^{\circ} \mathrm{C}$ and $15 \mathrm{~cm}$ to $20 \mathrm{~cm}$ rise in sea level, in the $21^{\text {st }}$ century some 85 years later the global average temperature will show another plus of $1.1^{\circ} \mathrm{C}$ percent to $5.4{ }^{\circ} \mathrm{C}$ percent. However, these 85 years, later increase of global warming depends on how much human being will pollute the environment. Climate change has various direct or indirect negative impacts on a human being. Of which, negatively affect health and well-being of plants, pasture, rangeland, and livestock production. Globally, the horticultural crops (vegetables) such as tomatoes, onions, and fruits are more sensitive to the Earth's climate change unlike to other grains (Seid, Yeshi, 2013).

A research that has been done under the title "adaptation to climate change in the agriculture sector in the semi-arid region of Nigeria" an average mean temperature and rainfall data were collected from 1938 to 2007; the author (Peter, 2010) contended that in between 1938 to 1972 the temperature was $28.24^{\circ} \mathrm{C}$ and the rainfall amounted to 
$937 \mathrm{~mm}$. However, in the year 1973 to 2007 temperature has been increased to $29.14^{\circ} \mathrm{C}$ and rainfall reduced to $758 \mathrm{~mm}$ in Nigeria. As a result, in the coming 85 years Nigeria will become one member of 2.5 to $4.5^{\circ} \mathrm{C}$ (medium to high temperature) because of the negative effects of climate change. This increase in temperature seeks climate adaptation to curve its negative impacts. At least it will affect directly the prices of agricultural products. A research conducted under a title 'the development and evaluation of onion and cabbage vegetables wholesale price forecasting model' in Ethiopia using 2004 to 2014 data witnessed that onion price shows a constant price rise in 2012 and 2013 (Sohyun et al., 2015). Thus, a total of 21.3 percent supply of onion output reduction was registered in these two years that has been caused by weather inconvenience to the product. As a result, causes the price of onion to increase sharply up plus motivates producers to produce more lately.Among the many factors which contribute for the consumption food inflation of the globe to increase are: Climate and weather change, increases in oil and energy prices, biofuels, and increase in global food demand (Net Comm, 2014). Stock and Watson (2000) have been introduced the distribution lag model in the context of estimating the dynamic causal effects on orange juice prices and Florida weather using monthly collected time series data of 1950 to 2000, concluded that as the weather gets cold the price of juice gets higher over time.

Vegetable crops are very important due to their higher yield potential, higher return and high nutritional value and suitability for small land holding farmers. Vegetables provide proteins, minerals and vitamins required for human nutrition ((Anum et al., 2015).

\section{Materials and Methods}

Description of the study area: Tigrai is the Northern most of Ethiopia's federal states located at 12012' and 14032' North latitude and between 36030' and 40030' East longitude. Mekelle city the northern star is the capital of the region. The state of Tigrai shares common borders with Eritrea in the north, the regional state of Afar in the east, the regional state of Amhara in the south, and the republic of Sudan in the west with more than 5million populations. Although the region has a number of legends about its history, the well-known and documented history of Tigrai begins in the eighth century B.C. (Yeha), and with the founding of the Aksumite Kingdom around 300 B.C.

Data type and source of data: The data of this research is taken from secondary sources. It was collected from two famous sources: first, from the National Meteorology Agency of Ethiopia Mekelle directorate branch; second, from Tigrai Agricultural Marketing Promotion Agency (TAMPA) starting from 2009 to 2015.

Model Specification and Estimation: Time series data is nothing but it's a data collected for a single entity at multiple points in time. By and large, time series regression models are relevant mainly for at least two well mentioned functions. Thus, to estimate the dynamic causal effects and forecasting future situation based on the lag values we have estimated (Stock, Watson, 2000).In the economics literature, the distributed lag models are highly useful for the consumer, producer, and government behaviors economic units that had been implemented by different researchers (Richard Roll, 1984; 
Hamilton, 1994; Stock, Watson, 2000; Wooldridge, 2009). Especially, distributed lag models are essential not only in estimating the previous year (lag value) but also useful in estimating current year value of defining a variable.

In a nutshell, the dynamic causal effect of the paper is modeled as here below:

$P_{i w t}=\beta_{0}+\beta_{1} P_{i w t-1}+\beta_{2} P_{i w t-2}+\beta_{3} P_{i w t-3}+\beta_{4} P_{i w t-4}+\beta_{5} P_{i w t-5}+\beta_{6} P_{i w t-6}$ $+\alpha_{1} T_{i w t-1}+\alpha_{2} T_{i w t-2}+\alpha_{3} T_{i w t-3}+\alpha_{4} T_{i w t-4}+\alpha_{5} T_{i w t-5}+\alpha_{6} T_{i w t-6}+\varepsilon_{t} \ldots \ldots$ (1) Where, $P_{t}=$ the current prices of tomato, onion, and potato in the specified woreda ${ }^{3}$ $i=$ number of vegetable items (tomato, onion, and potato) used in the estimation $w=$ number of woreda $\quad \beta_{0}=$ constant $\quad \mathrm{t}=$ time measured in years

$\beta_{1}=$ the immediate effect of a unit change in $P_{i w t}$ on $P_{t}$ holding constant past $P_{t}$ (one period lag dynamic multiplier effect) short $\beta_{2}=$ two year dynamic multiplier, ceteris paribus Pt, Pt-1, Pt-2, Pt-3 ...

$\beta_{3}=$ three year dynamic multiplier effect of change in Pt-2 on $P_{i w t}$, ceteris paribus Pt, Pt-1, Pt-3, $\quad \beta_{4}=$ four year dynamic multiplier effect of change in Pt-3 on $P_{\text {iwt }}$, ceteris paribus

$\beta_{6}=$ six year dynamic multiplier effect of change in Pt 5 on $P_{i w t}$, ceteris paribus

$T=$ the average monthly temperature of every woreda $\alpha_{1}=$ one year lag dynamic multiplier effect of temperature on $P_{i w t}$, ceteris paribus $\alpha_{2}=$ two year lag dynamic multiplier effect of temperature on $P_{i w t}$, ceteris paribus $\alpha_{6}=$ six year lag dynamic multiplier effect of temperature on $P_{i w t}$, , ceteris paribus

$\varepsilon_{t}=$ includes both measurement error and the effect of omitted determinants of $P_{i w t}$, orstochastic term or/ and error term. A priori expectation is stated as follows: first, represent the coefficients to estimate the short term effects of variation in temperature on the dependent variable (price of vegetables) that is $\beta_{1}>0, \beta_{2}>0, \beta_{3}>$ $0, \beta_{4}>0, \beta_{5}>0$, and $\beta_{6}>0$. And the long run expectation is also stated as follows: $\alpha_{1}>0, \alpha_{2}>0, \alpha_{3}>0, \alpha_{4}>0, \alpha_{5}>0$, and $\alpha_{6}$.

Gujarati (2004) those parameters $\alpha, \alpha 0, \alpha 1, \alpha 2 \ldots \alpha 6$ in distributed lag models can possibly be estimated using classical least square method. However, Gujarati, 2001 criticizes certain points concerning to estimates in distributed lag models. These are: first there is a difficulty to know a pre-information in the model regarding to how long the lag period will be; second, when a data set that can estimate the lag period is not set up, degree of freedom is continuously decreased, and the last important challenge is that variables decided as defining variables are in a multiple linear relationships. Consequently, in resolving the aforementioned failures Koyck has been developed an econometric model, since 1954. Lags in an explanatory variable affect the explained variable to some extent and the weight of these lags decrease, the model is reduced and thus made to estimate the regression equation. Koyck (1954) assumed that in an infinitely distributed lag model for example, all ' $\beta$ 's had the same signs and geometrically reduced so as to obtain the reduced model. Similarly, in determining the order of an auto regression (AR) balancing the marginal benefit of including more lags against the marginal cost of additional estimation uncertainty is essential. If the order of an estimated AR is too low, show and as we were omitted valuable information contained in

3 Woreda in this context is an administrative structure of governance next to that of zone level. 
the more distant lagged values. Conversely, if the order of an estimated AR is too high, revealed that as it was estimated more coefficients than necessary, which in turn creates additional estimation error into our forecast trends (Stock, Watson, 2000). When using information criterion to estimate the lag lengths two important things has to be considered. Thus: first, as is the case for the AR, all the candidate models must be estimated over the same sample that is the number of observations used to estimate the model. Time (T) must be equal for all models. Second, when there are multiple predictors, this approach is computationally demanding because it requires computing many combinations of the lag parameters (many different models).Lastly, the paper made different econometric tests such as Stationarity /random walk/ unit root, Break, Serial Correlation/ Autocorrelation, and Co-integration so as to assure the robustness of the results.

\section{Empirical Results and Data Analysis}

Descriptive Analysis: There was a high variation of vegetable prices every year in tomato, potato, and onion items due to climate change over the past seven years, ceteris paribus. Tomato the vital vegetable consumed both in urban and rural population has recorded the highest inflation (211 percent) as compared to potato and onion. As it can be observed in table 4.1, the price of tomato increased from 4.5 Birr in the past seven years to 14 Birr. Whereas, potato and onion vegetables were rose up more than 152 and 154 percent consecutively. These highest vegetable inflation records were witnessed the highest climate vulnerability hence vegetables are sensitive to temperature, ceteris paribus.

Table 1. Consumable Vegetable Inflation in Tigrai (2009 to 2015).

\begin{tabular}{|l|l|l|l|l|l|}
\hline Vegetables & Budget Year & $\begin{array}{l}\text { Price in } \\
(\text { Birr })\end{array}$ & Price in (US\$) & \% increase & Unit \\
\hline & 2009 & 4.2 & 0.2 & - & \\
\hline price of potato & 2010 & 4.56 & 0.21 & 9 & KG \\
\hline & 2011 & 4.64 & 0.22 & 17.5 & KG \\
\hline & 2012 & 5.42 & 0.25 & 17.35 & KG \\
\hline & 2013 & 6.2 & 0.3 & 14 & KG \\
\hline & 2014 & 7 & 0.32 & 11 & KG \\
\hline & 2015 & 10.6 & 0.5 & 51 & KG \\
\hline & 2009 & 5.34 & 0.24 & - & KG \\
\hline & 2010 & 5.8 & 0.26 & 8 & KG \\
\hline & 2011 & 6.2 & 0.28 & 7.7 & KG \\
\hline & 2012 & 9.5 & 0.42 & 53 & KG \\
\hline & 2013 & 10.5 & 0.48 & 11 & KG \\
\hline & 2014 & 11.8 & 0.54 & 12.4 & KG \\
\hline & 2015 & 13.54 & 0.62 & 15 & KG \\
\hline & 2009 & 4.5 & 0.2 & - & KG \\
\hline
\end{tabular}




\begin{tabular}{|l|l|l|l|l|l|}
\hline Vegetables & Budget Year & $\begin{array}{l}\text { Price in } \\
(\text { Birr) }\end{array}$ & Price in (US\$) & \% increase & Unit \\
\hline price of tomato & 2010 & 5 & 0.23 & 11 & KG \\
\hline & 2011 & 6 & 0.27 & 20 & KG \\
\hline & 2012 & 8.25 & 0.38 & 38 & KG \\
\hline & 2013 & 9.5 & 0.43 & 15 & KG \\
\hline & 2014 & 12 & 0.55 & 26 & KG \\
\hline & 2015 & 14 & 0.64 & 17 & KG \\
\hline
\end{tabular}

Source: Computed from the Collected Secondary Data, 2016.

Note: A Kilogram (KG) the unit of measurement in our case is equivalent to one kilogram. Similarly, the current official money exchange rate in Ethiopia November 2016 was taken (1US\$=22 Birr).

Figure 1. Direct Trends of Price of Vegetables and Temperature in Tigrai (2009-15) Figure4.1. Direct trends of price of tomato vegetables

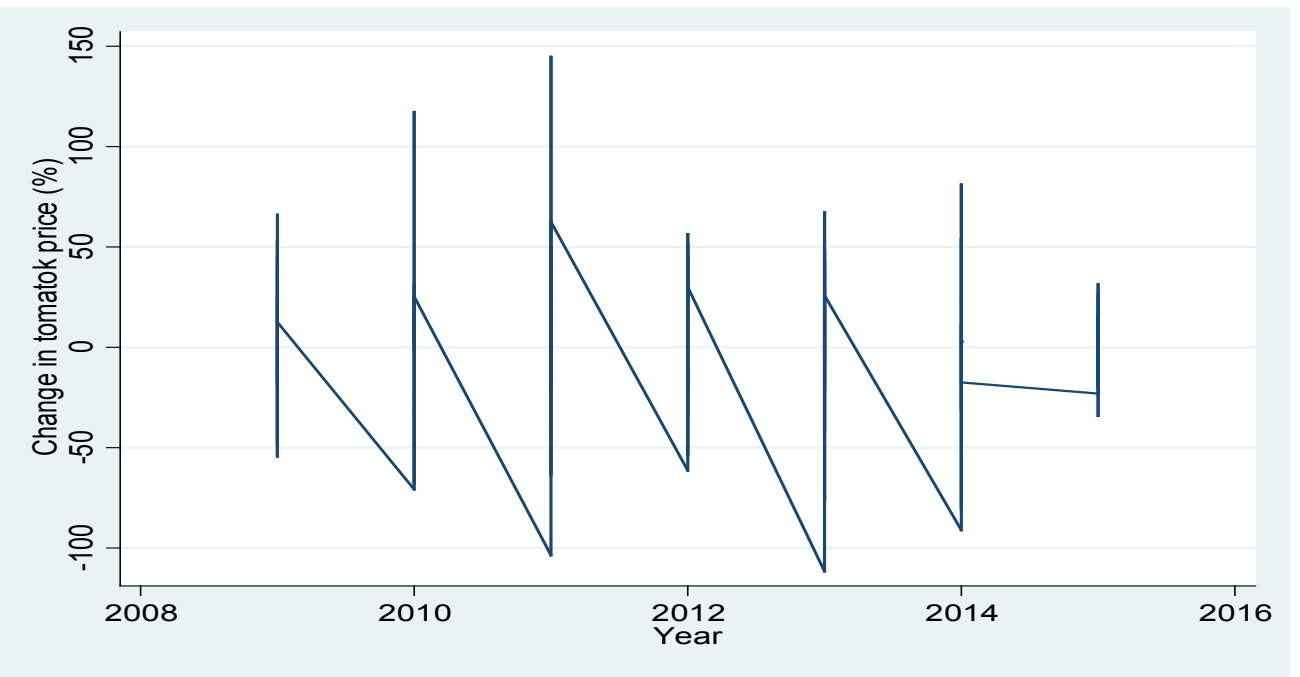

Source: Computed from the collected data at hand, 2016.

The direct trends of the price of tomato show a higher increase over the past seven years as compared to the climate change increased by lower than 1 degree centigrade. 
Figure 2. Direct trends of price of potato vegetables

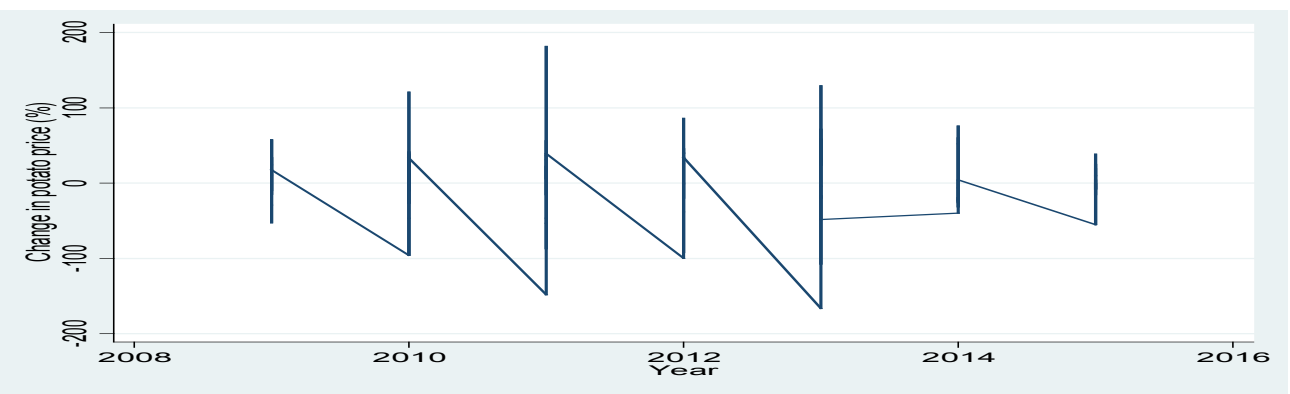

Source: Computed from the collected data at hand, 2016.

Similarly, the direct trend of the price of potato and onion show a higher increase over the past seven years as compared to the climate change increased by lower than $1{ }^{\circ} \mathrm{C}$.

Figure 3. Percentage Change of Price of Vegetables and Temperature (2009 to 2015) Percentage change (the indirect) trends of price of potato vegetables

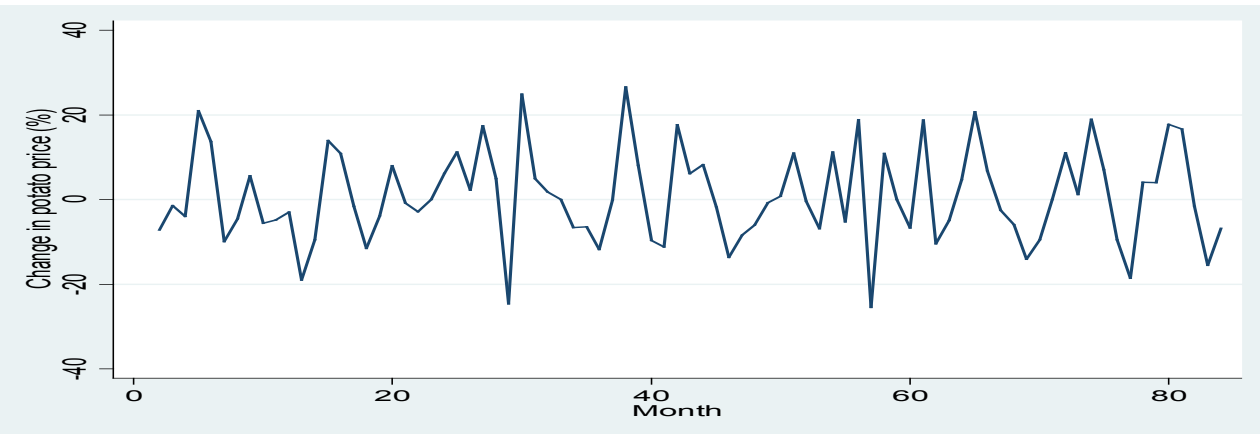

Source: Computed from the collected data at hand, 2016.

Figure 4. Percentage change (the indirect) trends of price of tomato vegetables

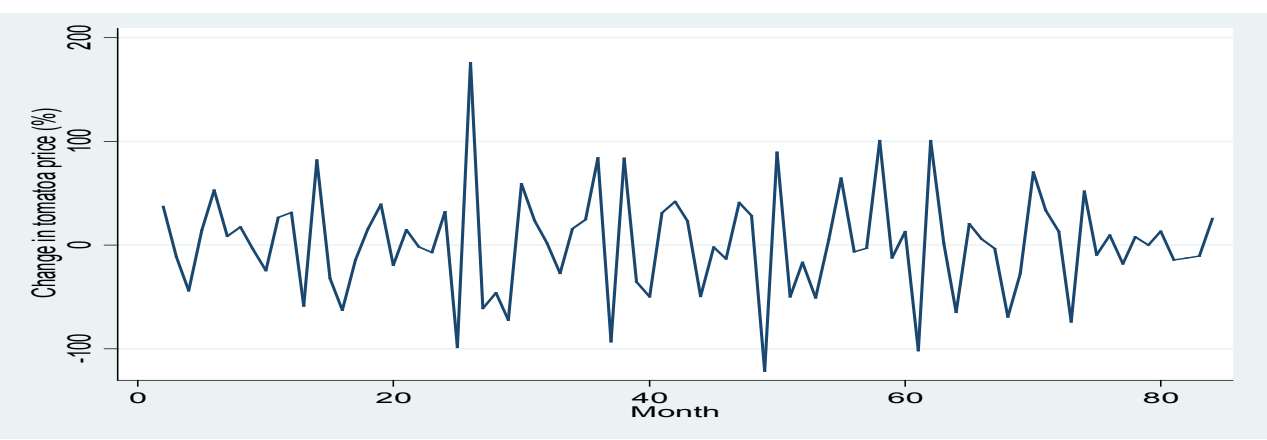

Source: Computed from the collected data at hand, 2016. 
The percentage change and two-way change which is better measurement as compared to that of the direct trends revealed that there were price ups and downs in vegetable price similar to the direct trends, but somehow smoother. In fact, in the $25^{\text {th }}$ month (January 2011) and $45^{\text {th }}$ month (June 2012), the vegetable price (more of potato) was inflated in line with temperature. The prices of potato show in the last seven years almost an increasing trend every month with a slight change. Opposite to what is said, in the $24^{\text {th }}$ month (September 2010); 35 th month (August 2011); $55^{\text {th }}$ month (April 2013); $75^{\text {th }}$ month (November 2015); above $80^{\text {th }}$ month (June 2015) the price of vegetables have fallen down dramatically.

\section{Lag Length Selection Process}

After using Final prediction error (FPE), Akaike information criterion (AIC), Schwarz's Bayesian information criterion (SBIC) and Hannan-Quinni information criterion (HQIC) to select the appropriate lag length in our study; we select the best lag length at which the values of information criterions are minimal. The result is therefore reported on the tables 4.2 to 4.4 .

Table 2. Price of potato in Tigrai (2009 to 2015)

\begin{tabular}{|l|l|l|l|l|l|l|l|l|}
\hline Lag & LL & LR & Df & P & FPE & AIC & HQIC & SBIC \\
\hline 0 & -319.53 & & & & -13.04 & -8.24 & -8.24 & -8.36 \\
\hline 1 & -237.88 & -163 & 4 & -0.00 & 1.78 & $6.39^{*}$ & $6.39^{*}$ & $6.46^{*}$ \\
\hline 2 & -234.29 & 7.19 & 4 & 0.126 & 1.89 & 6.36 & 6.36 & 6.58 \\
\hline 3 & -232.52 & 3.59 & 4 & 0.474 & 1.94 & 6.40 & 6.40 & 6.70 \\
\hline 4 & -225.14 & 14.55 & 4 & 0.005 & 1.70 & 6.41 & 6.41 & 6.78 \\
\hline 5 & -218.62 & 13.52 & 4 & 0.011 & 1.69 & 6.45 & 6.45 & 6.84 \\
\hline 6 & -213.61 & $10.09 *$ & 4 & 0.040 & $1.61 *$ & 6.44 & 6.44 & 6.95 \\
\hline
\end{tabular}

Source: Computed from the collected data at hand, 2016.

The maximum selection based on the AIC criterion in the price of potato is lag six. Thus, all the lags beyond lag six are irrelevant to explain the causality of the dependent variable.

Table 3. Price of onion in Tigrai (2009 to 2015)

\begin{tabular}{|l|l|l|l|l|l|l|l|l|}
\hline Lag & LL & LR & Df & P & FPE & AIC & HQIC & SBIC \\
\hline 0 & -388.9 & & & & 77.3 & 10.10 & 10.04 & 10.09 \\
\hline 1 & -333.5 & 110.7 & 4 & 0.00 & 20.7 & 8.70 & 8.75 & 8.83 \\
\hline 2 & -321.2 & 24.7 & 4 & 0.00 & 16.7 & 8.50 & $8.62^{*}$ & $8.75^{*}$ \\
\hline 3 & -316.4 & 9.6 & 4 & 0.05 & 16.4 & 8.47 & 8.64 & 8.87 \\
\hline 4 & -314.9 & 2.8 & 4 & 0.06 & 17.5 & 8.53 & 8.75 & 9.07 \\
\hline 5 & -308.8 & 12.3 & 4 & 0.02 & 16.6 & 8.5 & 8.74 & 9.11 \\
\hline 6 & -303.3 & $10.9^{*}$ & 4 & 0.03 & $16.1^{*}$ & $8.45^{*}$ & 8.76 & 9.26 \\
\hline
\end{tabular}

Source: Computed from the collected data at hand, 2016.

Similarly, based on the same criterion we select lag six for the price of onion in Table 4.3. All the lags beyond lag six do not have explaining power. 
Table 4. Price of tomato in Tigrai (2009 to 2015)

\begin{tabular}{|l|l|l|l|l|l|l|l|l|}
\hline Lag & LL & LR & Df & P & FPE & AIC & HQIC & SBIC \\
\hline 0 & -403.62 & - & - & - & 112.7 & 10.5 & 10.45 & 10.49 \\
\hline 1 & -370.18 & 66.9 & 4 & 0.00 & 52.9 & 9.7 & 9.48 & 9.90 \\
\hline 2 & -356.98 & 26.3 & 4 & 0.00 & 41.8 & 9.4 & $9.52^{*}$ & $9.75^{*}$ \\
\hline 3 & -354.83 & 4.3 & 4 & 0.35 & 43.8 & 9.5 & 9.68 & 9.85 \\
\hline 4 & -352.23 & 5.1 & 4 & 0.28 & 45.7 & 9.45 & 9.71 & 10.03 \\
\hline 5 & -341.42 & $21.63^{*}$ & 4 & 0.00 & $38.4^{*}$ & $9.31^{*}$ & 9.58 & 9.98 \\
\hline 6 & -337.93 & 7.12 & 4 & 0.13 & 38.9 & 9.34 & 9.68 & 10.19 \\
\hline
\end{tabular}

Source: Computed from the collected data at hand, 2016.

We select the favorable lag length lag five; hence the AIC criterion is minimal.

Table 5. Augmented Dicky-Fuller Test for unit root on the price of potato

Augmented Dickey-Fuller test for unit root Number of obs $=77$

------Interpolated Dickey-Fuller -------

Test $\quad 1 \%$ Critical $\quad 5 \%$ Critical $\quad 10 \%$ Critical

Statistic Value Value Value

$\mathrm{Z}(\mathrm{t}) \quad-5.006 \quad-3.542 \quad-2.908 \quad-2.589$

MacKinnon approximate $p$-value for $Z(t)=0.0000$

\begin{tabular}{|l|l|l|l|l|ll|}
\hline D.dprpotato & Coef. & Std. Err. & $\mathrm{T}$ & $\mathrm{P}>|\mathrm{t}|$ & {$[95 \%$ Conf. Interval] } \\
\hline L1. & 2.079 & .404 & -5.01 & $0.000^{* * *}$ & -2.803522 & -1.206057 \\
\hline LD. & .9172 & .348 & 2.63 & $0.010^{* *}$ & .2219196 & 1.612305 \\
\hline L2D. & .612 & .298 & 2.27 & $0.026^{* *}$ & .0812326 & 1.245792 \\
\hline L3D. & .417 & .234 & 1.74 & $0.085^{*}$ & -.0590551 & .8845106 \\
\hline L4D. & .155 & .177 & 0.86 & 0.392 & -.2019922 & .5088638 \\
\hline L5D. & .072 & .115 & 0.65 & 0.516 & -.160065 & .31569 \\
\hline & 1.63 & 1.276 & 1.30 & 0.198 & -.8883144 & 4.21352 \\
cons & \multicolumn{7}{|l|}{} & & & \\
\hline
\end{tabular}

Source: Computed from the collected data at hand, 2016.

According to the ADF result, the Test Statistic value (5.006) is higher than that of these three critical values ranging from 2.58 to 3.42 . As a result, the lags were non-stationary at level (normal regression), but become stationary after first difference (with change (d)) equals to what is in Table 4.5 difference of the variable. One degree centigrade $\left({ }^{\circ} \mathrm{C}\right)$ temperature increase caused the price of potato to increase almost by double. Similarly, in the year 2010 (LD) as the temperature increased by $1^{\circ} \mathrm{C}$ in Tigrai in the previous year, the average price of potato vegetable increased close to 92 percent, ceteris paribus. Moreover, the price of potato increased by around 66 percent in 2011(L2D) because of $1^{\circ} \mathrm{C}$ increase in the average temperature in Tigrai. In the L3D (2012) a $1^{\circ} \mathrm{C}$ rise in the 
average temperature caused 41 percent rise in the price of potato. The research output is consistent and valid with the previous researches (Sohyun et al., 2015; Anum et al., 2015; Kamau 2014; Honrao, 2014; Bezabih et al., 2014; Gebreegziabher et al., 2014; Bezabih, Mekonnen, 2014; Dick et al., 2013; Emerta, 2013; John, 2007; CEEPA, WB, 2006).

Table 6. Augmented Dicky-Fuller Test for unit root on price of onion

Augmented Dickey-Fuller test for unit root Number of obs $=74$

--------- Interpolated Dickey-Fuller ---------

Test $\quad 1 \%$ Critical $\quad 5 \%$ Critical $\quad 10 \%$ Critical

Statistic Value Value Value

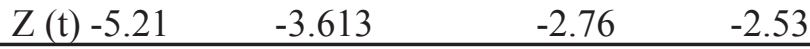

MacKinnon approximate $\mathrm{p}$-value for $\mathrm{Z}(\mathrm{t})=0.000$

\begin{tabular}{|c|c|c|c|c|c|}
\hline D.dpronion & Coef. & Std. Err. & $\mathrm{T}$ & $\mathrm{P}>|\mathrm{t}|$ & [95\% Conf. Interval] \\
\hline L1. & 2.227 & .438 & -5.15 & $0.000 * * *$ & \begin{tabular}{|ll}
-3.083496 & -1.36165
\end{tabular} \\
\hline LD. & .994 & .385 & 2.60 & $0.012 * *$ & $.2289833 \quad 1.753126$ \\
\hline L2D. & .961 & .323 & 2.91 & $0.005 * * *$ & $.3037943 \quad 1.633308$ \\
\hline L3D. & .738 & .282 & 2.56 & $0.013 * *$ & $.1616442 \quad 1.305153$ \\
\hline L4D. & .517 & .235 & 2.20 & $0.031 * *$ & $\begin{array}{ll}.0474421 & .9908538\end{array}$ \\
\hline L5D. & .392 & .187 & 2.11 & $0.039 * *$ & $.0213952 \quad .7686692$ \\
\hline L6D & .167 & .121 & 1.39 & 0.170 & $\begin{array}{|ll|}-.0732893 & .4080241\end{array}$ \\
\hline _cons & 2.34 & 3.076 & 0.77 & 0.445 & \begin{tabular}{|ll}
-3.690435 & 8.312723 \\
\end{tabular} \\
\hline
\end{tabular}

Source: Computed from the collected data at hand, 2016.

Similar to the price of potato above, in (2009) as an example (L1); one degree-centigrade $\left({ }^{\circ} \mathrm{C}\right)$ temperature increase caused the price of onion to increase almost more than double (220 percent) in the northernmost part of Ethiopia. Moreover, in the year 2010 (LD) as the temperature increased by $1{ }^{\circ} \mathrm{C}$ in Tigrai, the average price of onion vegetables were increased close to 100 percent, ceteris paribus. The price of onion tuber vegetables increased by around 96 percent in 2011 (L2D) because of $1^{\circ} \mathrm{C}$ increase in the average temperature in Tigrai holding other effects constant. 
Table 7. Augmented Dicky-Fuller Test for unit root on the price of tomato

Augmented Dickey-Fuller test for unit root Number of obs $=76$

-------- Interpolated Dickey-Fuller

$\begin{array}{cccc}\text { Test } & 1 \% \text { Critical } & 5 \% \text { Critical } & 10 \% \text { Critical } \\ \text { Statistic } & \text { Value } & \text { Value } & \text { Value }\end{array}$

$\mathrm{Z}(\mathrm{t}) \quad-5.152 \quad-3.544 \quad-2.909 \quad-2.590$

MacKinnon approximate $\mathrm{p}$-value for $\mathrm{Z}(\mathrm{t})=0.0000$

\begin{tabular}{|c|c|c|c|c|c|}
\hline D.dponion & Coef. & Std. Err. & $\mathrm{T}$ & $\mathrm{P}>|\mathrm{t}|$ & [95\% Conf. Interval] \\
\hline L1. & 3.19 & .51 & -5.51 & $0.000 * * *$ & $-4.242314 \quad-1.98504$ \\
\hline LD. & 1.54 & .51 & 3.03 & $003 * * *$ & .532707 \\
\hline L2D. & 1.18 & .49 & 2.61 & $0.011 * *$ & .2803417 \\
\hline L3D. & .98 & .38 & 2.41 & $0.019 * *$ & .1591325 \\
\hline L4D. & .71 & .26 & 2.59 & $0.012 * *$ & .1758298 \\
\hline L5D. & .54 & .23 & 2.81 & 0.006 *** & .1702975 \\
\hline L6D. & .28 & .14 & 2.01 & $0.048 * *$ & .0016207 .467538 \\
\hline cons & 4.05 & 5.84 & 0.69 & 0.493 & -7.685399 \\
\hline
\end{tabular}

Source: Computed from the collected data at hand, 2016.

The price of tomato in (2009) that is (L1); a single degree centigrade $\left({ }^{\circ} \mathrm{C}\right)$ temperature increase in the previous year caused the price of tomato vegetable in Tigrai to increase almost more than threefold (310percent). Likewise, in the year 2010 (LD) as the temperature increased by $1{ }^{\circ} \mathrm{C}$ in Tigrai, the average price of tomato vegetables was increased close to 155 percent, ceteris paribus. Even the price of tomato vegetables increased by approximately to 118 percent in 2011 (L2D) because of $1^{\circ} \mathrm{C}$ increase in the average temperature in Tigrai holding other effects constant (Gebrekiros et al., 2016; Anum et al., 2015; Aklilu et al., 2015; Emerta, 2013; John, 2007). Lastly, in the L5D (2013) and L6D (2014) only, a $1{ }^{\circ} \mathrm{C}$ rise in the average temperature in the previous year in Tigrai was caused close to 58 percent and 23 percent increase in the price of tomato, ceteris paribus. As it can be inferred from the mentioned tables above, the price increase is higher in the tomato vegetables because of the average temperature increase by $1^{\circ} \mathrm{C}$ in Tigrai (2009 to 2015), unlike that of potato and onion.

\section{Co-integration Test}

This test refers to the fact that two or more series share a stochastic trend. After we made a statistic test, therefore, found the variables are co-integrated. That mean price of vegetables has direct relationship with the average temperature increase by $1{ }^{\circ} \mathrm{C}$ increase in Tigrai in the last seven years. Hence, the test statistic in the table 4.4 below witnessed that with a larger value as compared to that of the 5 percent critical value. 
Table 8. The result of Co-integrated test

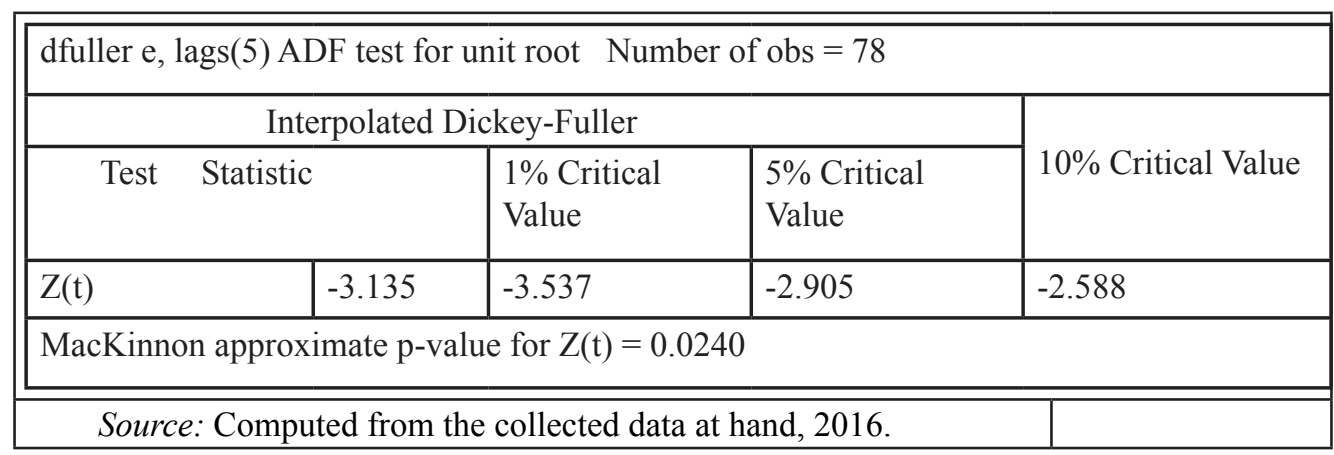

Similarly, the regression output witnessed that there is no serial correlation problem test.

\section{Conclusion and Recommendation}

The research is motivated to find out a new way in the price effect of climate change on the average price inflation of vegetables using time series data collected every month from 2009 to 20015 in Tigrai, Ethiopia. A univariate econometric analysis and finite distributed lag model were implemented in defining the variables and the outcome. Due to climate change inTigrai, tomato the vital vegetable consumed both in urban and rural population has recorded the highest inflation (211 percent) from 2009 to 2015 as compared to potato and onion. Whereas, potato and onion vegetables were rose up more than 152 and 154 percent consecutively. More to the point, the price of tomato in (2009), and a single degree centigrade temperature increase caused the price of tomato vegetables to increase almost more than threefold (310 percent) in 2015. In 2010, when the temperature increases close to $1^{\circ} \mathrm{C}$, the average prices of tomato vegetables were increased 155 percent, ceteris paribus. Even the price of tomato vegetables were increased by around 118 percent in 2011 because of $1{ }^{\circ} \mathrm{C}$ increase in the average temperature in Tigrai holding other effects into account. Lastly, in 2013 and $2014,1^{\circ} \mathrm{C}$ increase in the average temperature in Tigrai were caused close to 58 percent and 23 percent rise in the price of tomato alone, ceteris paribus. As it can be inferred, the price increase is higher in the tomato vegetables because of the average temperature increase by $1^{\circ} \mathrm{C}$ in Tigrai (2009 to 2015) than that of onion and potato. Although the average prices of potato and onion increment were not equal to the increment in tomato, but showed near to the tomato vegetables price rise over the past seven years. In a nutshell, applying different econometric tests confirmed us that there were high vegetable price ups and downs every year parallel to the average temperature increment in Tigrai (2009 to 2015) though the degree of increment varied overtime thereby resulted in low agricultural outputs (Anum et al., 2015; Aklilu et al., 2015; Weldesilassie et al., 2015; Kamau, 2014; Honrao, 2014; Bezabih et al., 2014; Gebreegziabher et al., 2014; Bezabih, Mekonnen, 2014; CEEPA, WB, 2006). The research recommended that so as to get many healthy advantages in feeding vegetables often at an affordable price by many of us, implementing due climate adaptive strategies is decisive in taking best experiences from the renewable energy innovator countries and produce surplus agricultural outputs including vegetables thereby reduce consumption price hike. 


\section{Literature}

1. Admit Z., Haile, K., James, W., (2015): African Economic Outlook. Ethiopia. Addis Ababa, Ethiopia. AfDB, OECD, UNDP 2015.

2. Aklilu, N., Yitagesu, K., Abiy, A., Tigist, A., Kidane, D., (2015): Onion production for Income Generation in Small Scale Irrigation Users Agropastoral households of Ethiopia. Ethiopian Institute of Agricultural Research.

3. Anum, F., Saleem, A., Sobia, N., (2015): Trends in Wholesale Prices of onion and potato in major markets of Pakistan: A time series Analysis. Pakistan J. Agric. Res. Vol. 28 No.2, 2015.

4. Ayana, S., Beyene, S., Nebil, S., Sertse, S., Tefera, T., (2011): FDRE Ministry of Agriculture. Agriculture Sector Programme of Plan on Adaptation to Climate Change.

5. Ben, G., Mehroosh, T., (2013): Welfare Analysis of Changing Food Prices: A Nonparametric Examination of Export Ban on Rice in India. ISSN 1753 5816. No. 177.

6. Bezabih, E., Amsalu, A., Tesfaye, B., Milkessa, T., (2014): Scoping Study on Vegetables Seed Systems and Policy in Ethiopia. Final Report Addis Ababa, Ethiopia.

7. Bezabih, M., Mekonnen, A., (2014): Is it the climate or the weather? Differential economic impacts of climatic factors in Ethiopia. CCEP Working Paper No.165 and GRICCE Working Paper No.148.

8. CEEPA, WB, (2006): Climate Change and African Agriculture.Policy Note No. 25, August 2006, CEEPA.

9. Demeke, M., Pangrazio, G., Maetz, M., FAO, (2009): Country responses to the food security crisis: Nature and preliminary implications of the policies pursued.

10. Dick, D., Bo, S., (2012): African Development Bank Working Paper Series. The Dynamics of Inflation in Ethiopia and Kenya.

11. Dick, D., Josef, L., Yohannes, A., (2013): Inflation Dynamics and Food Prices in Ethiopia. Working Papers in Economics No. 478.

12. Donald, M., (2008): A Note on Rising Food Prices. The World Bank Development Prospects Group. Policy Research Working Paper 4682.

13. Emerta, A., (2010): Inflation and Economic Growth: An estimating a threshold level of inflation in Ethiopia. Ethiopian Economic Association, Ninth proceeding, Vo1.2 pages 203-233. Addis Ababa, Ethiopia.

14. Emerta, A., (2013): Climate Change, Growth, and Poverty in Ethiopia. CCAPS. Working Paper No.3. 
15. Endale, G., (2013): An overview of horticultural crops with emphasis on vegetables production in Ethiopia. A country Report. Presented at the workshop Tutaabsoluta: Meeting the challenge of the tomato leaf miner.

16. Ethiopian Economic Association (EEA), (2008): Climate Change and Development Adaptation Measures Economic Focus, 11(1) Addis Ababa, Ethiopia.

17. Ethiopian Investment Agency (EIA), (2012): Investment Opportunity Profile for the Production of Fruits and Vegetables in Ethiopia.

18. FAO, IFAD, IMF, OECD, UNCTAD, WFP, WB, WTO, IFPRI, UN HLTF, (2011): Price Volatility in Food and Agricultural Markets: Policy Responses Policy Report including contributions.

19. Fred, K., Hayden, S., (2008): Price Trends Are Similar for Fruits, Vegetables, and Snack Foods.

20. G. Erdal, H., Esengun, K., (2009): Agricultural Academy an Analysis of production and Price relationship for potato in Turkey: A distributed lag Model Application. Bulgarian Journal of Agricultural Science, 15 (No 3) 2009, 243250 .

21. Gebreegziabher, Z., Mekonnen, A., Deribe, R., Abera, S., Kassahun, M. M., (2014): Climate change can have significant negative impacts on Ethiopia's agriculture. Research Brief. Addis Ababa, Ethiopia. EDRI, EfD.

22. Gebrekiros, G., Araya, A., Yemane, T., (2016): Modeling impact of climate change and variability sorghum production in Southern zone of Tigray, Ethiopia. J Earth Sci clim change. 7:322 doi:10.4172/2157-7617.1000322.

23. Hamilton, J. D. (1994): Time Series Analysis. Princeton: Princeton University Press.

24. Honrao, P., (2014): Modeling Volatility of Price of Agricultural Products in India: Using Arima-Garch Applications. Volume : 4 | Issue : 9 | September 2014 | ISSN - 2249-555X.

25. IMF, WB, (2011): Responding to Global food price volatility and its impact on food security.

26. James, S., Mark, W., (2000): Introduction to Econometrics. Harvard and Princeton University.

27. Jeffrey, W., (2009): Introductory Econometrics. A Modern Approach. Michigan State of University. $4^{\text {th }}$ Edition.

28. Jeni, K., Josef, L., (2007): Welfare Impacts of Food Price Inflation in Ethiopia.

29. John, (2007): Drought, Climate Change and Food Prices in Australia.

30. Josef, L., Dick, D., Yohannes, B., (2009): Inflation Dynamics and Food Prices in an Agricultural Economy. The Case of Ethiopia. Policy Research Working Paper 4969. 
31. Kamau, G., (2014): Modeling of Wholesale Prices for Selected Vegetables Using Time Series Models in Kenya. I56/79482/2012.

32. Kassa Teka et al., (2012): Impact of climate change on small-holder farming: A case of Eastern Tigray, Northern Ethiopia. African Crop Science Journal, Vol.201, Issue Supplement S2,pp.337-347.

33. Khan, Sendanji, (2001): Threshold Effects in the Relationship between Inflation and Growth, IMF Staff Papers, Vol. 48, No. 1.

34. Kofi, A., (2012): The Impact of Rising Food Prices on Household Welfare in Ghana. Ph.D Research proposal. Policy Note", World Bank (draft). University of Ghana Department of Economics.

35. Koyck, L. M., (1954): Distributed Lags and Investment Analysis. North Holland Publishing Company, Amsterdam, pp. 21-50.

36. Maros, I., Will, M., (2008): Implications of higher global food prices for poverty in low-income countries. Agricultural Economics 39 (2008) supplement 405416.

37. Muluken, Y., (2015): Annual inflation rises $11.9 \%$ in one year. Monday, 10 August 2015 09:18.

38. N. Gujarati Damodar, (2004): Basic Econometrics. $4^{\text {th }}$ edition.

39. Net Comm, (2014): Education Phase three. Food Price and Food Choice. Seventh Framework Programme.

40. Peter, O., (2010): Adaptation to Climate Change in the Agricultural Sector in the Semi-arid Region of Nigeria.2nd International Conference: Climate, Sustainability and Development in Semi-arid Regions.

41. Roll, R., (1984): Orange Juice and Weather. The American Economic Review, Vol., 74, No.5 (Dec., 1984), 861-880.

42. Seid, H., Yeshi, M., (2013): Enhancing communities' adaptive capacity to climate change in drought-prone hotspots of the Blue Nile Basin in Ethiopia. Unpublished. Training Manual on Highland Fruit and Vegetable Production. ILRI- UNEP-Wollo University pilot project, Ethiopia.

43. Sohyun, K., Hyun, N., Cheolho, S., Youngchan, C., (2015): The Development and Evaluation of Onion and Cabbage Wholesale Price Forecasting Models. International Journal of Software Engineering and Its Applications. Vol.9,No.8(2015),pp.37-50 http://dx.doi.org/10.14257/ijseia.2015.9.8.04.

44. Tom, C., Joe, R., (2008): Food Price Inflation: Causes and Impacts.

45. UNDP, (2014): Country Economics Brief. Ethiopia. Analysis Issue No.1/ Feb.2014.

46. WB, (2005): Explaining Sources of Food Price Inflation in Ethiopia: "A Just in Time Explaining Food Price Inflation; Policy Note by the World Bank. 
47. WB, (2011): Food, Financial Crises, and Complex Derivatives: A Tale of High Stakes Innovation and Diversification.

48. Weldesilassie, A., Assefa, B., Hagos, A., (2015): Productivity and Welfare Impact of Climate Change in Sugarcane and Cotton Producing Regions of Ethiopia. EDRI, Addis Ababa, Ethiopia.

49. WFP, (2011): Policy options to address price volatility and high prices.

50. WFP, FAO, (2011): The State of Food Insecurity in the World. Economic crises - impacts and lessons learned.

51. WFP, FAO, IFAD, (2011): The State of Food Insecurity in the World. How does international price volatility affect domestic economies and food security? 
ECONOMICS OF

AGRICULTURE

\section{CONTENT}

1. Adriana Radosavac, Desimir Knežević

ECONOMIC IMPORTANCE OF USE

OF PESTICIDES IN WHEAT PRODUCTION . . . . . . . . . . . 1323

2. Berhe Gebregewergs, Muuz Hadush

DOES CLIMATE CHANGE AFFECT PRICE OF VEGETABLES:

EVIDENCE FROM TIGRAI, NORTHERN MOST ETHIOPIA. . . . .1335

3. Grujica Vico, Aleksandra Govedarica-Lučić, Zoran Rajić, Radomir Bodiroga, Ivan Mičić, Silvija Zec Sambol, Marija Mičić

MULTI ATTRIBUTE ASSESSMENT APPROACH

IN VEGETABLE PRODUCTION . . . . . . . . . . . . . . 1355

4. Igor Trandafilović, Vesna Conić, Aleksandra Blagojević

IMPACT OF DEMOGRAPHIC FACTORS ON

ENVIRONMENTALLY CONSCIOUS PURCHASE BEHAVIOUR. . .1365

5. Imre Milán Harcsa

STUDY ON THE POTENTIAL OF SUBCONTRACT

PALINKA DISTILLATION . . . . . . . . . . . . . . 1379

6. Jelena Andrašić, Vera Mirović, Nada Milenković, Branimir Kalaš, Miloš Pjanić

IMPACT OF TAKEOVER PROCESS ON EMPLOYEES -

EVIDENCE FROM FOOD, RETAIL AND FINANCIAL SECTOR . . .1393

7. Jelena Birovljev, Danilo Đokić, Bojan Matkovski, Žana Kleut

ECONOMIC PERFORMANCES OF AGRICULTURE

OF CEFTA AND FORMER CEFTA COUNTRIES . . . . . . . . . . 1413

8. Jelena Marković, Svetlana Stevović

SUSTAINABILITY OF CHEMICAL SOIL QUALITY

IN SOUTHERN MORAVA RIVER VALLEY

IN CORELLATION WITH THE FLOODING $\ldots \ldots \ldots \ldots \ldots$ 
9. Mile Peševski, Zoran Milovančević

THE CHANGES IN THE USAGE OF AGRICULTURAL LAND

IN EASTERN REGION OF REPUBLIC OF MACEDONIA

BETWEEN $1991-2030 \ldots \ldots$. . . . . . . . . . . . . . . . . . . . . . .

10. Odjuvwuederhie Emmanuel Inoni, 'Oraye Dicta Ogisi, Felix Odemero Achoja

PROFITABILITY AND TECHNICAL EFFICIENCY IN HOMESTEAD

CATFISH PRODUCTION IN DELTA STATE, NIGERIA . . . . . . . 1449

11. Olja Munitlak - Ivanović, Jovan Zubović, Petar Mitić

RELATIONSHIP BETWEEN SUSTAINABLE DEVELOPMENT AND

GREEN ECONOMY - EMPHASIS ON GREEN FINANCE

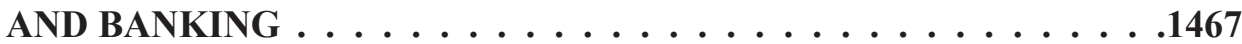

12. Petar Munćan, Dragica Božić

FARM SIZE AS A FACTOR OF EMLOYMENT AND INCOME

OF MEMBERS OF FAMILY FARMS . . . . . . . . . . . . . 1483

13. Rade Popović, Mira Kovljenić

EFFICIENCY OF WHEAT PRODUCTION ON FARMS

IN THE REPUBLIC OF SERBIA . . . . . . . . . . . . . . . . . . . . . . . . .

14. Radovan Damnjanović, Snežana Krstić, Milena Knežević, Svetislav Stanković,

Dejan Jeremić

THE DISCRIMINANT ANALYSIS APPLIED TO THE

DIFFERENTIATION OF SOIL TYPES . . . . . . . . . . . . 1513

15. Slavica Otović, Dunja Demirović, Kristina Košić, Aleksandra Vujko

FOSTERING ENTERPRENUERSHIP AT HIGH SCHOOLS:

A CASE OF RURAL AREAS IN VOJVODINA (SERBIA) . . . . . . .1523

16. Vladimir Ilić, Ivan Bauer, Anastazija Tanja Đelić, Aleksandar Nešković

INSTITUTIONAL SUPPORT FOR STRENGTHENING

ENTREPRENEURSHIP IN AGRICULTURAL PRODUCTION

OF THE REPUBLIC OF SERBIA . . . . . . . . . . . . . . . . . . . . . . . .

17. Boro Krstić, Zorica Vasiljević, Miroslav Nedeljković

INSURANCE CONTRACT AS THE BASIS FOR THE SAFETY OF

AGRICULTURAL PRODUCERS IN THE REPUBLIC OF SRPSKA • . 1555

18. Dejan Sekulić, Aleksandar Petrović, Vladimir Dimitrijević

WHO ARE WINE TOURISTS? AN EMPIRICAL INVESTIGATION

OF SEGMENTS IN SERBIAN WINE TOURISM . . . . . . . . . . . . . 
19. Milan Beslać, Ćorić Goran

FINANCIAL AND PRODUCTION ASPECTS OF GENETICALLY MODIFIED ORGANISMS $\ldots \ldots \ldots \ldots \ldots \ldots \ldots \ldots \ldots$

20. Mlađan Maksimović, Darjan Karabašević, Miodrag Brzaković, Pavle Brzaković THE EFFECTS RESULTING FROM THE APPLICATION OF THE CONCEPT OF THE SUSTAINABLE DEVELOPMENT OF RURAL TOURISM ON STARA PLANINA . . . . . . . . . . . . . . . .1595

21. Vesna Popović, Predrag Vuković, Milivoje Ćosić FOOD SAFETY AND QUALITY POLICY IN THE REPUBLIC OF SERBIA . . . . . . . . . . . . . . . . 1607

22. Radovan Pejanović, Danica Glavaš-Trbić, Mirela Tomaš-Simin PROBLEMS OF AGRICULTURAL AND RURAL DEVELOPMENT IN SERBIA AND NECESSITY OF NEW AGRICULTURAL POLICY . . . .1619

23. Saša Marković, Slavoljub Vujović, Aleksandar Damnjanović MARKETING AND HIGHER EDUCATION CONDITION IN SERBIA . . . . . . . . . . . . . . . . 1635

24. Semir Vehapi, Marina Milanović THE EFFECT OF MARKET ORIENTATION ON BUSINESS PERFORMANCE OF SERBIAN ORGANIC PRODUCERS . . . . . 1651

25. Suad Bećirović, Šemsudin Plojović, Enis Ujkanović, Senadin Plojović CHALLENGES AT STARTING AN AGRIBUSINESS IN THE HILLY MOUNTAINOUS REGIONS OF SOUTHWEST SERBIA . . . . . . . .1669

26. Vladimir Zakić, Vlado Kovačević, Jelena Damnjanović SIGNIFICANCE OF FINACIAL LITERACY FOR THE AGRICULTURAL HOLDINGS IN SERBIA . . . . . . . . . . 1687

27. Željko Bjelajac, Marijana Dukić Mijatović, Željko Vojinović PROTECTION OF LAND IN THE REPUBLIC OF SERBIA AND ECOLOGICAL SECURITY WITH REGARD TO STRATEGIC AND LEGAL FRAMEWORKS . . . . . . . . . .1703 